\author{
Article \\ Doi 10.5943/sif/1/1/5 \\ Copyright $@$ C Mushroom Research Foundation 2016
}

\title{
Saprobic Dothideomycetes in Thailand: Vaginatispora appendiculata sp. nov. (Lophiostomataceae) introduced based on morphological and molecular data
}

\author{
Wanasinghe $\mathrm{DN}^{1,2}$, Jones EBG ${ }^{3}$, Dissanayake $\mathrm{AJ}^{1,2,4}$ and Hyde $\mathrm{KD}^{1,2,3,4^{*}}$ \\ ${ }^{1}$ Center of Excellence in Fungal Research, Mae Fah Luang University, Chiang Rai, 57100, Thailand \\ ${ }^{2}$ School of Science, Mae Fah Luang University, Chiang Rai, 57100, Thailand \\ ${ }^{3}$ Department of Botany and Microbiology, King Saudi University, Riyadh, Saudi Arabia \\ ${ }^{4}$ Institute of Plant and Environment Protection, Beijing Academy of Agriculture and Forestry Sciences, No. 9 of \\ ShuGuangHuaYuanZhongLu, Haidian District, Beijing 100097, P. R. China
}

Wanasinghe DN, Jones EBG, Dissanayake AJ, Hyde KD 2016 - Saprobic Dothideomycetes in Thailand: Vaginatispora appendiculata sp. nov. (Lophiostomataceae) introduced based on morphological and molecular data. Studies in Fungi 1(1), 56-68, Doi 10.5943/sif/1/1/5

\begin{abstract}
In order to establish the evolutionary relationships and resolve the polyphyletic nature of Dothideomycetes, we are studying their natural classification based on both morphology and multigene phylogeny. In this paper we introduce Vaginatispora appendiculata, a novel species on dead twigs from southern Thailand. Morphological character differences and analyses of combined LSU, TEF, SSU and ITS sequence datasets support the validity of the new species and its placement in Vaginatispora (Lophiostomataceae).
\end{abstract}

Keywords - Appendages - Massarina - Phylogeny

\section{Introduction}

We have been studying the diverse members of Dothideomycetes to provide a natural classification based on both morphology and phylogeny (Boonmee et al. 2011, 2012, Liu et al. 2011, 2012, 2015, Hyde et al. 2013, Ariyawansa et al. 2014, 2015a, 2015b, Chomnunti et al. 2014, Phookamsak et al. 2014, 2015, Thambugala et al. 2014, 2015, Wanasinghe et al. 2014a, 2014b, 2015, Wijayawardene et al. 2014, 2014b, 2015, 2016, Tian et al. 2015). This paper reports on a saprobic pleosporalean species which was collected on dead twigs in southern Thailand and identified as a new species of Vaginatispora K.D. Hyde. Vaginatispora was introduced by Hyde (1995) in Massarinaceae Munk to accommodate Vaginatispora aquatica K.D. Hyde. The genus and species was characterized by 'depressed globose ascomata, immersed beneath a blackened neck, with a slot-like ostiole, numerous and filamentous pseudoparaphyses, cylindrical to clavate asci and narrowly ellipsoidal, hyaline, 2-celled ascospores with a mucilaginous collar around its equator and a spreading papilionaceous sheath' (Hyde 1995, Zhang et al. 2014). Vaginatispora was considered as a synonym of Massarina for a long time (Hyde et al. 1992, Read et al. 1997). Few studies have been conducted on the family placement of Vaginatispora and recently Thambugala et al. (2015) confirmed it as a separate genus in Lophiostomataceae Sacc. based on both morphological characteristics and phylogeny. 
Combined analyses of LSU, TEF, SSU and ITS sequence data, using maximum-likelihood (ML), maximum-parsimony (MP) and MrBayes (BYPP), clearly show that Vaginatispora appendiculata is a well-supported species (100\% ML \& MP / 1.00 BYPP, Fig. 1) in Vaginatispora.

\section{Materials and methods}

\section{Sample collection, morphological studies and isolation}

Specimens were collected from Thailand, and processed and examined following the method described in Wanasinghe et al. (2014a). Hand sections of the fruiting structures were mounted in water for microscopic studies and photomicrography. The taxon was examined using a Nikon ECLIPSE 80i compound microscope and photographed with a Canon 450D digital camera fitted to the microscope. Measurements were made with the Tarosoft (R) Image Frame Work program and images used for figures processed with Adobe Photoshop CS3 Extended version 10.0 software (Adobe Systems, USA).

Single ascospore isolation was carried out following the method described in Chomnunti et al. (2014). Germinated spores were individually transferred to Potato dextrose agar (PDA) plates and grown at $16^{\circ} \mathrm{C}$ in the daylight. Colony colour and other characters were observed and measured after three weeks. The specimens are deposited at the Mae Fah Luang University (MFLU) Herbarium, Chiang Rai, Thailand. Living culture is also deposited at the Culture Collection of Mae Fah Luang University (MFLUCC). Faces of Fungi number is provided in Jayasiri et al. (2015) and Index Fungorum numbers as in Index Fungorum (2016).

\section{DNA extraction and PCR amplification}

Fungal isolates were grown on potato-dextrose agar (PDA) for $3-4$ weeks at $16{ }^{\circ} \mathrm{C}$ and total genomic DNA was extracted from 50 to $100 \mathrm{mg}$ of axenic mycelium scraped from the edges of the growing culture (Wu et al. 2001). Mycelium was ground to a fine powder with liquid nitrogen and DNA was extracted using the Biospin Fungus Genomic DNA Extraction Kit-BSC14S1 (BioFlux, P.R. China) following the instructions of the manufacturer.

DNA sequence data was obtained from the partial sequences of four genes, the internal transcribed spacers (5.8S, ITS), small subunit rDNA (18S, SSU), large subunit (28S, LSU) and translation elongation factor 1-alpha gene (TEF). Nuclear ITS was amplified using the primers ITS5 and ITS4 (White et al. 1990). LSU was amplified using the primers LROR and LR5 (Vilgalys \& Hester 1990). SSU was amplified using the primers NS1 and NS4 (White et al. 1990), TEF was amplified using primers EF1-983F and EF1-2218R (Rehner 2001).

Polymerase chain reaction (PCR) was carried out following the protocol of Wanasinghe et al. (2014a). PCR amplification was confirmed on $1 \%$ agarose electrophoresis gels stained with ethidium bromide. The amplified PCR fragments were sent to a commercial sequencing provider (BGI, Ltd Shenzhen, P.R. China). The nucleotide sequence data acquired is deposited in GenBank (Table 1).

\section{Sequencing and sequence alignment}

Other sequences used in the analyses (Table 1) were obtained from GenBank based on recently published data (Ariyawansa et al. 2015a, Thambugala et al. 2015). The multiple alignments were automatically done by MAFFT v. 7.036 (http://mafft.cbrc.jp/alignment/server/index.html; Katoh \& Standley 2013) using the default settings and latter refined where necessary, using BioEdit v. 7.0.5.2 (Hall 1999).

\section{Phylogenetic analysis}

Parsimony analysis was carried with the heuristic search option in PAUP (Phylogenetic Analysis Using Parsimony) v. $4.0 \mathrm{~b} 10$ (Swofford 2002), with the following parameter settings, as described in Wanasinghe et al. (2014a): characters unordered with equal weight, random taxon addition, branch swapping with tree bisection-reconnection (TBR) algorithm, branches collapsing if 
Table 1 Taxa used in the phylogenetic analysis and their corresponding GenBank numbers. The newly generated sequences are indicated in bold

\begin{tabular}{|c|c|c|c|c|c|}
\hline \multirow{2}{*}{ Taxon } & \multirow{2}{*}{ Culture Accession No } & \multicolumn{4}{|c|}{ GenBank Accession No. } \\
\hline & & LSU & TEF & SSU & ITS \\
\hline Alpestrisphaeria terricola & SC-12 & JX985750 & - & JX985749 & JN662930 \\
\hline Biappendiculispora japonica & MAFF 239452 & AB619005 & LC001744 & AB618686 & LC001728 \\
\hline Biappendiculispora japonica & JCM 17671 & AB619007 & LC001746 & AB618688 & LC001730 \\
\hline Biappendiculispora japonica & JCM 17670 & AB619006 & LC001745 & AB618687 & LC001729 \\
\hline Capulatispora sagittiformis & JCM 15100 & AB369267 & LC001756 & AB618693 & AB369268 \\
\hline Coelodictyosporium muriforme & MFLUCC 13-0351 & KP888641 & KR075163 & KP899127 & KP899136 \\
\hline Coelodictyosporium pseudodictyosporium & MFLUCC 13-0451 & KR025862 & - & - & KR025858 \\
\hline Dimorphiopsis brachystegiae & СРC 22679 & KF777213 & - & - & KF777160 \\
\hline Floricola striata & JK $5603 \mathrm{~K}$ & GU479785 & - & GU479751 & - \\
\hline Floricola striata & JK 5678I & GU301813 & GU479852 & GU296149 & - \\
\hline Guttulispora crataegi & MFLUCC 13-0442 & KP888639 & KR075161 & KP899125 & KP899134 \\
\hline Guttulispora crataegi & MFLUCC 14-0993 & KР888640 & KR075162 & KP899126 & KP899135 \\
\hline Lophiopoacea paramacrostoma & MFLUCC 11-0463 & KP888636 & - & KP899122 & - \\
\hline Lophiopoacea winteri & JCM 17648/KT 740 & AB619017 & LC001763 & AB618699 & JN942969 \\
\hline Lophiopoacea winteri & MAFF 239454 & AB619018 & LC001764 & AB618700 & JN942968 \\
\hline Lophiostoma alpigenum & GKM 1091b & GU385193 & GU327758 & - & - \\
\hline Lophiostoma heterosporum & CBS 644.86 & AY016369 & DQ497609 & AY016354 & GQ203795 \\
\hline Lophiostoma macrostomoides & CBS 123097 & FJ795439 & GU456277 & FJ795482 & - \\
\hline Lophiostoma macrostomum & JCM 13544 & AB619010 & LC001751 & AB618691 & ज942961 \\
\hline Lophiostoma macrostomum & $\begin{array}{c}\text { JCM 13546/ MAFF } \\
239447\end{array}$ & AB433274 & LC001753 & AB521732 & AB433276 \\
\hline Lophiostoma macrostomum & JCM 13545 & AB433273 & LC001752 & AB521731 & AB433275 \\
\hline Lophiostoma multiseptatum & JCM 17668 & AB619003 & LC001742 & AB618684 & LC001726 \\
\hline Lophiostoma multiseptatum & MAFF 239451 & AB619004 & LC001743 & AB618685 & LC001727 \\
\hline Lophiostoma quadrinucleatu & GKM1233 & GU385184 & GU327760 & - & - \\
\hline Lophiostoma semiliberum & JCM 13548 & AB619012 & LC001757 & AB618694 & JN942966 \\
\hline Lophiostoma semiliberum & JCM 13547 & AB619013 & LC001758 & AB618695 & JN942967 \\
\hline Lophiostoma semiliberum & $\begin{array}{c}\text { JCM 13549/MAFF } \\
239448\end{array}$ & AB619014 & LC001759 & AB618696 & JN942970 \\
\hline Lophiostoma triseptatum & SMH 2591 & GU385183 & - & - & - \\
\hline Lophiostoma tr & SMH 5287 & GU38 & - & - & - \\
\hline Lophiostoma viridarium & IFRDCC 2090 & FJ795443 & - & FJ795486 & - \\
\hline Melanomma pulvis-pyrius & CBS 124080 & GU456323 & GU456265 & GU456302 & - \\
\hline Neotrematosphaeria biappendiculata & KTC 1124 & GU205227 & - & GU205256 & - \\
\hline Paucispora quadrispora & KH 448 & LC001722 & 54 & LC001720 & LC001733 \\
\hline Paucispora quadrispora & $\begin{array}{c}\text { MAFF } 239455 / \mathrm{KT} \\
843\end{array}$ & AB619011 & LC001755 & AB618692 & LC001734 \\
\hline Paucispora versicolor & MAFF 244508 & AB918732 & LC001760 & LC001721 & AB918731 \\
\hline Platystomum actinidiae & KT 521 & JN941380 & LC001747 & JN941375 & JN942963 \\
\hline stomum actir & $\begin{array}{c}\text { JCM 13125/MAFF } \\
239635\end{array}$ & 41379 & LC001748 & JN941376 & JN942962 \\
\hline Platystomum actinidiae & IFRD 2014 & FJ795437 & - & FJ795480 & - \\
\hline Platystomum compressum & MFLUCC 13-0343 & KP888643 & KR075165 & KP899129 & - \\
\hline Platystomum crataegi & MFLUCC 14-0925 & КТ026109 & КT026121 & КT026113 & КT026117 \\
\hline Platystomum rosae & MFLUCC 15-0633 & KT026111 & - & KT026115 & KT026119 \\
\hline Platystomum salicicola & MFLUCC 15-0632 & КT026110 & - & КT026114 & КT026118 \\
\hline
\end{tabular}




\begin{tabular}{lccccc}
\hline \multicolumn{1}{c}{ Taxon } & Culture Accession No & \multicolumn{4}{c}{ GenBank Accession No. } \\
& $*$ & LSU & TEF & SSU & ITS \\
\hline Pseudolophiostoma vitigenum & JCM 13534/MAFF & AB619015 & LC001761 & AB618697 & LC001735 \\
Pseudolophiostoma vitigenum & 239459 & & & & \\
Pseudoplatystomum scabridisporum & JCM 17676 & AB619016 & LC001762 & AB618698 & LC001736 \\
Pseudoplatystomum scabridisporum & BCC 22835 & GQ925844 & GU479857 & GQ925831 & - \\
Sigarispora arundinis & BCC 22836 & GQ925845 & GU479856 & GQ925832 & - \\
Sigarispora arundinis & JCM 13550 & AB618998 & LC001737 & AB618679 & JN942964 \\
Sigarispora caudata & JCM 13551/MAFF & AB618999 & LC001738 & AB618680 & JN942965 \\
Sigarispora caulium & 239449 & & & & \\
Sigarispora caulium & MAFF 239453 & AB619000 & LC001739 & AB618681 & LC001723 \\
Sigarispora coronillae & MAFF 239450 & AB619001 & LC001740 & AB618682 & LC001724 \\
Sigarispora ravennica & JCM 17669 & AB619002 & LC001741 & AB618683 & LC001725 \\
Vaginatispora appendiculata & MFLUCC 14-0941 & KT026112 & - & KT026116 & KT026120 \\
Vaginatispora aquatica & MFLUCC 14-0005 & KP698414 & - & KP698415 & KP698413 \\
Vaginatispora armatispora & MFLUCC 16-0314 & KU743218 & KU743220 & KU743219 & KU743217 \\
Vaginatispora fuckelii & MFLUCC 11-0083 & KJ591576 & - & KJ591575 & KJ591577 \\
Vaginatispora fuckelii & HKLTCC 1562 & - & - & - & AF383955 \\
Vaginatispora sp. & JCM 17672 & AB619008 & LC001749 & AB618689 & LC001731 \\
\hline
\end{tabular}

*ANM: A.N. Miller, ATCC: American Type Culture Collection, Virginia, USA, BCC: BIOTEC Culture Collection, Bangkok, Thailand, BBH: BIOTEC Bangkok Herbarium, Thailand; CBS: Centraalbureau voor Schimmelcultures, Utrecht, The Netherlands, CPC: Working collection of Pedro Crous housed at CBS, DAOM: Plant Research Institute, Department of Agriculture (Mycology), Ottawa, Canada, GKM: G.K. Mugambi, IFRDCC: Culture Collection, International Fungal Research and Development Centre, Chinese Academy of Forestry, Kunming, China, JCM: the Japan Collection of Microorganisms, Japan, JK: J. Kohlmeyer, KT: K. Tanaka, KH: K. Hirayama, MAFF: Ministry of Agriculture, Forestry and Fisheries, Japan, MFLUCC: Mae Fah LuangUniversity Culture Collection, Chiang Rai, Thailand, NN: NovoNordisk culture collection (now Novozymes, Bagsvaerd,Denmark), SC: Department of Plant Pathology, Sichuan Agricultural University, SMH: S.M. Huhndorf.

the maximum branch length was zero. Alignment gaps were treated as missing characters in the analysis of the combine data set, where they occurred in relatively conserved regions. Parsimony bootstrap analyses were performed using the full heuristic search option, random stepwise addition, and 1000 replicates, with maxtrees set at 1000 . Descriptive tree statistics for parsimony (Tree Length [TL], Consistency Index [CI], Retention Index [RI], Relative Consistency Index [RC] and Homoplasy Index $[\mathrm{HI}]$ were calculated for trees generated under different optimality criteria. The Kishino-Hasegawa tests (Kishino \& Hasegawa 1989) were performed to determine whether the trees inferred under different optimality criteria were meaningfully different. Maximum parsimony bootstrap values (MP) equal or greater than $60 \%$ are given above each node in red (Fig 1).

Evolutionary models for phylogenetic analyses were selected independently for each locus using MrModeltest v. 3.7 (Posada \& Crandall 1998) under the Akaike Information Criterion (AIC) implemented in both PAUP v. $4.0 \mathrm{~b} 10$ and MrBayes v. 3. Phylogenetic reconstructions of combined gene trees were performed using both Bayesian Inference (BI) and Maximum Likelihood (ML) criteria.

Maximum-likelihood (ML) analysis was performed in RAxML (Stamatakis 2008) implemented in raxmlGUI v.0.9b2 (Silvestro \& Michalak 2010), employing mixed models of evolution settings of the program and Bootstrap support obtained by running 1000 pseudoreplicates. The online tool Findmodel was used to determine the best nucleotide substitution (http://www.hiv.lanl.gov/content/sequence/findmodel/findmodel.html) model for each partition. Maximum Likelihood bootstrap values (ML) equal or greater than $60 \%$ are given above each node in black (Fig. 1). 
A Bayesian analysis was conducted with MrBayes v. 3.1.2 (Huelsenbeck \& Ronqvist 2001) to evaluate Posterior probabilities (PP) (Rannala \& Yang 1996; Zhaxybayeva \& Gogarten 2002) by Markov Chain Monte Carlo sampling (BMCMC). Two parallel runs were conducted, using the default settings, but with the following adjustments:

Six simultaneous Markov chains were run for 2,000,000 generations and trees were sampled every 100th generation and 20,000 trees were obtained. The first 4,000 trees, representing the burnin phase of the analyses and discarded. The remaining 16000 trees were used for calculating PP in the majority rule consensus tree (Cai et al. 2006, 2008, Ariyawansa et al. 2015). Branches with Bayesian posterior probabilities greater than 0.9 above each node in black (Fig. 1).

Phylograms were visualized with FigTree v1.4.0 program (Rambaut 2012) and reorganized in Microsoft power point (2007) and Adobe Illustrator ${ }^{\circledR}$ CS5 (Version 15.0.0, Adobe ${ }^{\circledR}$, San Jose, CA).

\section{Results and Discussion}

\section{Phylogenetic analysis}

The combined LSU, TEF, SSU and ITS gene dataset comprised 57 sequences from all genera in Lophiostomataceae whose sequences are available in GenBank, plus two strains from Floricolaceae (Floricola striata JK 5603K and JK 56781) and our new strain of $V$. appendiculata. Melanomma pulvis-pyrius (CBS 124080) is the outgroup taxon (Fig. 1). Four different alignments corresponding to each individual gene and a combined alignment of the four genes were analyzed. A best scoring RAxML tree is shown in Fig. 1, with the value of $-15629.448302(\mathrm{ln})$ and the following model parameters: alpha: 0.609592 and invar: $\Pi(\mathrm{A}): 0.249198, \Pi(\mathrm{C}): 0.239722, \Pi(\mathrm{G})$ : 0.266913 and $\Pi(\mathrm{T}): 0.244167$. All trees (ML, MP and BYPP) were similar in topology and did not differ significantly (data not shown) at the generic relationships, which is in agreement with previous studies based on multi-gene analyses (Ariyawansa et al. 2015, Thambugala et al. 2015).

This analysis comprised 3699 characters, of which 2905 were constant, 600 parsimonyinformative and 194 parsimony-uninformative. Four equally parsimonious trees were generated and the first was selected (Fig. 1). Bootstrap support (BS) values of ML and MP (equal to or above 60 $\%$ based on 1000 replicates) are shown on the upper branches with black (ML) and blue (MP). Branches with Bayesian posterior probabilities (PP) greater than 0.95 from MCMC analyses are given in bold. The Kishino-Hasegawa test shows length $=1994$ steps with $\mathrm{CI}=0.551, \mathrm{RI}=0.712$, $\mathrm{RC}=0.392$ and $\mathrm{HI}=0.449$.

Our strain of $V$. appendiculata (MFLUCC 16-0314) grouped in Lophiostomataceae, but separated from the other species of Vaginatispora with high bootstrap support (100\% ML \& MP / 1.00 BYPP, Fig. 1).

\section{Taxonomy}

Vaginatispora K.D. Hyde, Nova Hedwigia 61(1-2): 234 (1995)

Facesoffungi number: FoF00828

Type species: Vaginatispora aquatica K.D. Hyde, Nova Hedwigia 61(1-2): 235 (1995)

इLophiostoma vaginatispora Zhang, Hyde, Zhao, McKenzie \& Zhou,, Phytotaxa 176(1): 177 (2014)

Vaginatispora appendiculata Wanasinghe, E.B.G. Jones \& K.D. Hyde, sp. nov.

Fig. 2 Index Fungorum Number: IF551961

Facesoffungi Number: FoF 01926

Etymology - Name reflects the appendages in this species

Holotype - MFLU 16-0522

Saprobic on dead twigs in terrestrial habitat by waterfall. Sexual morph: Ascomata 300 $400 \mu \mathrm{m}$ high, $200-400 \mu \mathrm{m}$ diam. $(\mathrm{x}=387.3 \times 266.2 \mu \mathrm{m}, \mathrm{n}=10)$, scattered, immersed, coriaceous, black, globose to subglobose, ostiolate. Ostiole 100-200 $\mu \mathrm{m}$ high, 50-70 $\mu \mathrm{m}(\mathrm{x}=165.3 \times 63.9$ $\mu \mathrm{m}, \mathrm{n}=10$ ) diam., slit-like, central, with a crest-like papilla, with an irregular, pore-like opening, 


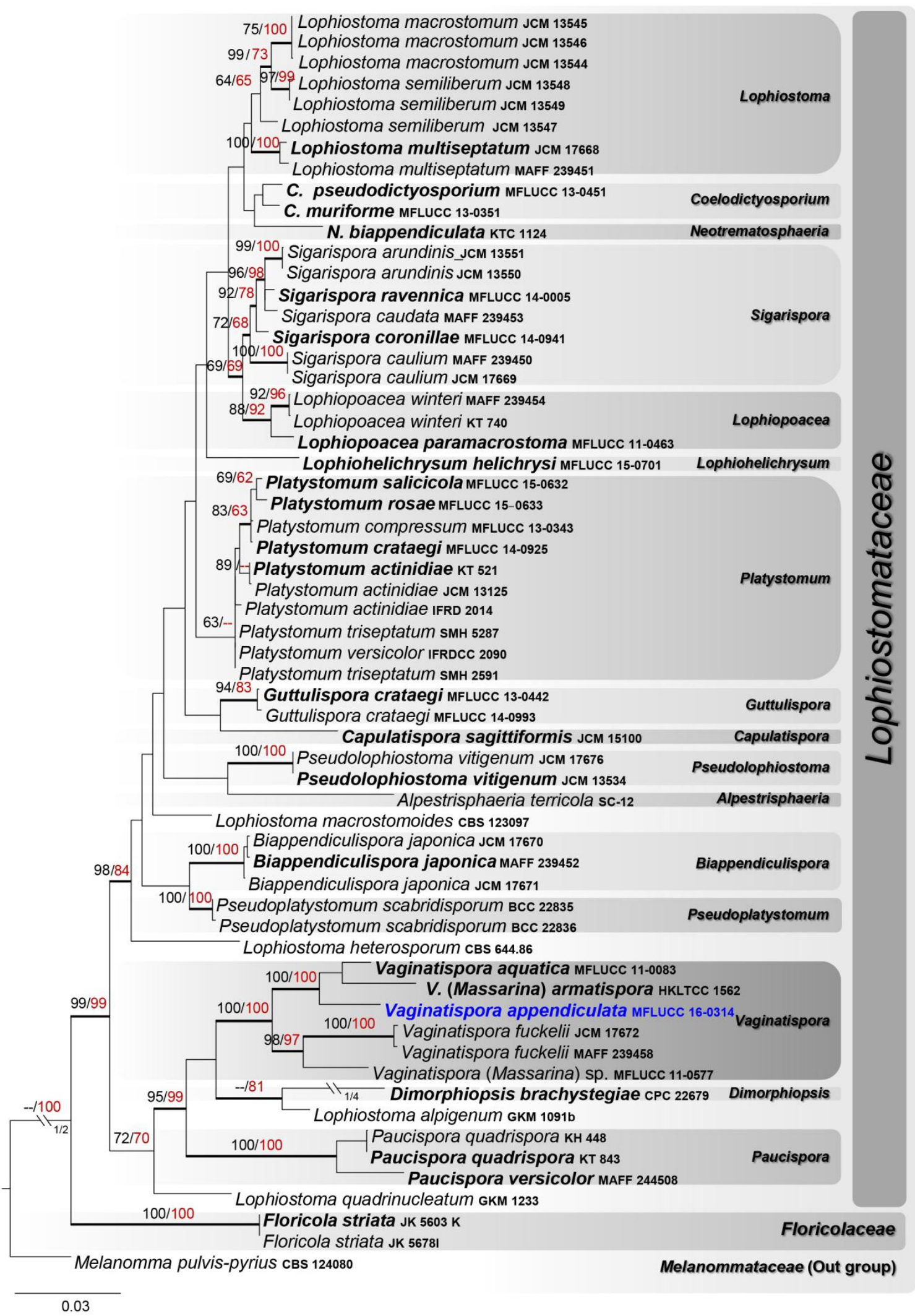

Fig. 1 - RAxML tree based on a combined dataset of LSU, TEF, SSU and ITS partial sequences. Bootstrap support values for maximum likelihood (ML, black) and maximum parsimony (MP, red) higher than $60 \%$ are defined as above the nodes and branches with Bayesian posterior probabilities (BYPP) greater than 0.90 are given in bold. The ex-type and reference strains are in bold; the new isolates are in blue. The tree is rooted to Melanomma pulvis-pyrius (CBS 124080). 
plugged by hyaline, filamentous hyphae, and occasionally lighter. Peridium 10-15 $\mu \mathrm{m}$ wide at the base, 20-30 $\mu \mathrm{m}$ wide in sides, composed of two layers, outer layer wider, comprising several layers with black, somewhat flattened cells of textura angularis, fusing and indistinguishable from the host tissues and inner layer comprising 2-4 layers of lightly pigmented to hyaline cells of textura angularis. Hamathecium comprising 3-4.5 $\mu \mathrm{m}(\mathrm{n}=30)$, wide septate, cellular pseudoparaphyses, situated between and above the asci, embedded in a gelatinous matrix. Asci 130-170 × 20-35 $\mu \mathrm{m}$ $(\mathrm{x}=158.9 \times 29 \mu \mathrm{m}, \mathrm{n}=35), 8$-spored, bitunicate, fissitunicate, cylindrical-clavate, with a developed pedicel $(10-30 \mu \mathrm{m}$ long; $\mathrm{x}=21 \mu \mathrm{m}, \mathrm{n}=30)$, apically rounded with an ocular chamber. Ascospores $40-45 \times 10-15 \mu \mathrm{m}(\mathrm{x}=43.3 \times 12.1 \mu \mathrm{m}, \mathrm{n}=50)$, uniseriate to partially overlapping $1-$ 2-seriate, hyaline, ellipsoidal, 1-septate, constricted at the septum, with 1-3, distinct large guttules in each cells, smooth-walled, with distinct hyaline appendages $(3-6 \mu \mathrm{m}$ long; $\mathrm{x}=4.8 \mu \mathrm{m}, \mathrm{n}=40)$ at both ends, without a mucilaginous sheath. Asexual morph: Undetermined.

Culture characteristics - Colonies on PDA: slow reaching $3 \mathrm{~cm}$ diam. after 4 weeks at $25^{\circ} \mathrm{C}$, dirty white at the beginning and dark grey at maturity, convex on the surface, undulate, smooth margins; reverse buff.

Known distribution - Thailand, on dead twigs.

Material examined - Thailand, Prachuap Khiri Khan, Bang Saphan, Ron Thong, Sai Khu Waterfall, on dead stem of undetermined sp., 29 July 2015, D.N. Wanasinghe (MFLU 16-0522, holotype) isotype in KUN, under the code of HKAS91945, ex-type living culture, MFLUCC 160314.

Gene sequence data: ITS - KU743217, LSU - KU743218, SSU - KU743219, TEF KU743220.

Vaginatispora armatispora (K.D. Hyde, Vrijmoed, Chinnaraj \& E.B.G. Jones) Wanasinghe, E.B.G. Jones \& K.D. Hyde, comb. nov.

$\equiv$ Massarina armatispora K.D. Hyde, Vrijmoed, Chinnaraj \& E.B.G. Jones, Bot. Mar. 35(4): 325 (1992)

$=$ Lophiostoma armatisporum (K.D. Hyde, Vrijmoed, Chinnaraj \& E.B.G. Jones) E.C.Y. Liew, Aptroot \& K.D. Hyde, Mycologia 94(5): 812 (2002)

Notes - Massarina armatispora was introduced by Hyde et al. (1992) in Massarina to accommodate an intertidal mangrove taxon from the coast of Southern China and India; which differed from other Massarina species at that time. Later, Liew et al. (2002) synonymised $M$. armatispora under Lophiostoma armatisporum based on both molecular (ITS) and morphological evidence. In this study $M$. armatispora grouped in Vaginatispora with high statistical support $(100 \% \mathrm{ML}, 100 \% \mathrm{MP}$ and $1.00 \mathrm{BYPP}$, Fig. 1). This fungus is morphologically more similar to Parapaucispora pseudoarmatispora Hay. Takah., K. Hiray. \& Kaz. Tanaka in its ascospores (Li et al. 2016). However, P. pseudoarmatispora groups separately from Vaginatispora in multi-gene phylogenetic analyses and has a close relationship with Lophiostoma alpigenum (Li et al. 2016).

\section{Key to species of Vaginatispora}

1. Semi-immersed ascomata with a diameter less than $250 \mu \mathrm{m}$, asci shorter than $100 \mu \mathrm{m}$ and ascospores smaller than $20 \mu \mathrm{m}$......

1. Immersed ascomata with a diameter more than $250 \mu \mathrm{m}$, asci longer than $100 \mu \mathrm{m}$ and ascospores larger than $20 \mu \mathrm{m}$.

2. Thick peridium (up to $100 \mu \mathrm{m}$ ), pseudoparaphyses less than $2.5 \mu \mathrm{m}$ wide and ascospores without appendages, with a papilionaceous sheath.....

2. Thin peridium (up to $30 \mu \mathrm{m}$ ), pseudoparaphyses more than $2.5 \mu \mathrm{m}$ wide and ascospores with appendages, without a sheath......

3. Pseudoparaphyses width less than $3 \mu \mathrm{m}$ wide, ascospores shorter than $40 \mu \mathrm{m}$ and lacking guttules.

V. armatispora

3. Pseudoparaphyses width more than $3 \mu \mathrm{m}$ wide, ascospores longer than $40 \mu \mathrm{m}$ and with distinct large guttules in each cell $\quad \boldsymbol{V}$. appendiculata 

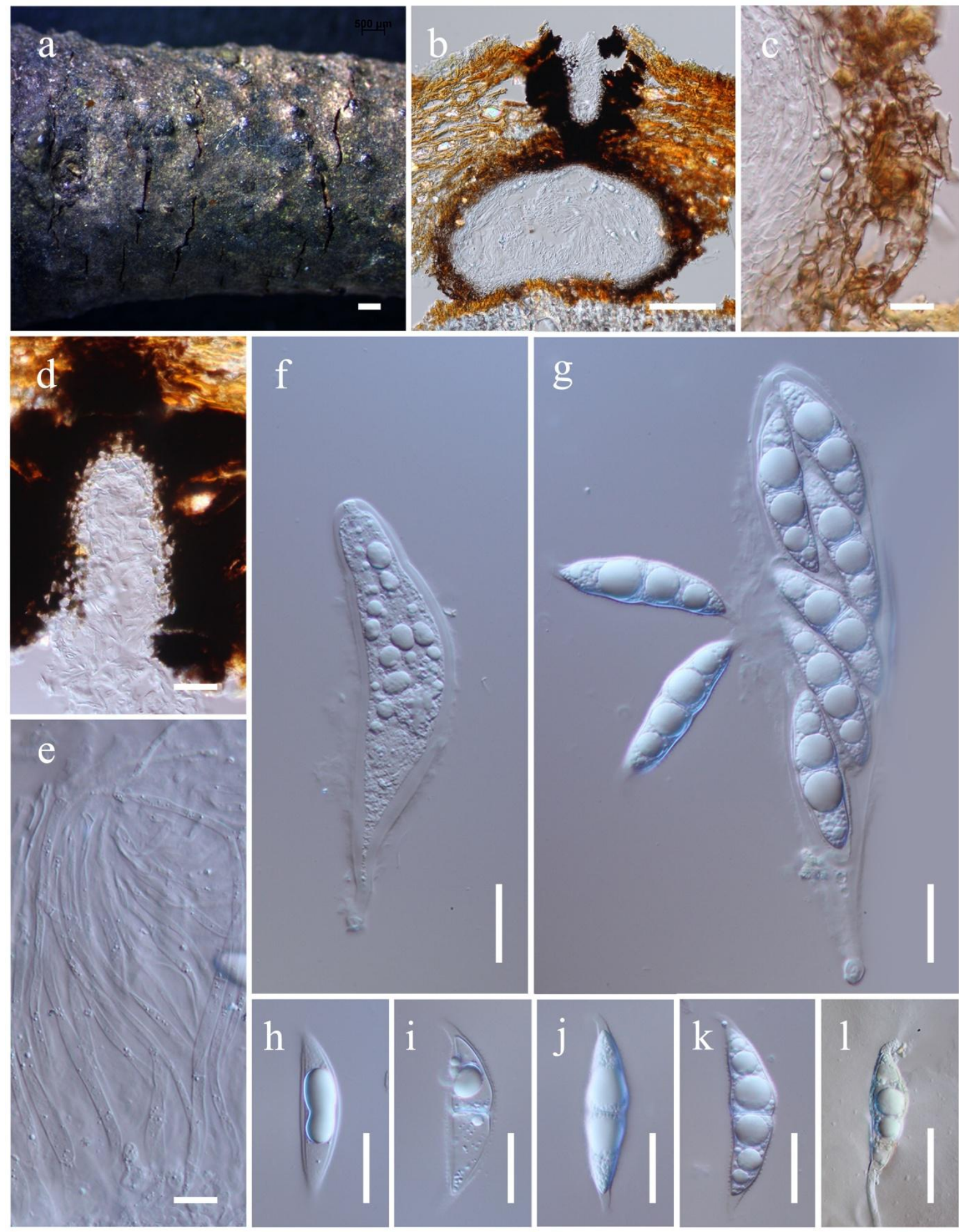

Fig. 2 - Vaginatispora appendiculata (holotype). a Appearance of ascomata on host substrate. b Section of ascoma. c Peridium. d Close up of ostiole. e Pseudoparaphyses. f, g Asci. h-k Ascospores. I Germinated spore. Scale bars: $\mathrm{a}=500 \mu \mathrm{m}, \mathrm{b}=100 \mu \mathrm{m}, \mathrm{c}, \mathrm{e}=10 \mu \mathrm{m}, \mathrm{d}, \mathrm{f}-1=20 \mu \mathrm{m}$.

\section{Discussion}

In our combined gene analyses of Lophiostomataceae (Fig. 1), taxa from the genus Vaginatispora formed a distinct clade with high bootstrap (100\% in ML and MP) and a high PP value (1.00 in Bayesian analysis). The type species Vaginatispora aquatica (MFLUCC 11-0083) $\mathrm{V}$. (Massarina) armatispora (HKLTCC 1562), V. fuckelii (JCM 17672 \& MAFF 239458) and 
Vaginatispora (Massarina) sp. (MFLUCC 11-0577) clustered together in a well-supported clade within the family Lophiostomataceae. Thus, we confirm their generic placement in Lophiostomataceae. Vaginatispora species are similar to Lophiostoma (L. macrostomum) and Lophiopoacea (L. winteri) in having a slot-like papillate ostiole, cylindro-clavate asci with a long pedicel, hyaline, 1-septate, euseptate ascospores. However, phylogenetically these taxa are not closely related with Vaginatispora strains (Fig. 1).

Our collection of $V$. appendiculata, grouped in a well-supported clade $(100 \% \mathrm{ML}, 100 \%$ $\mathrm{MP}$ and $1.00 \mathrm{PP}$ ) with $V$. aquatica and $V$. armatispora. However, $V$. appendiculata is different from $V$. aquatica in having ascospores without a sheath but with terminal appendages (Fig. 2), while $V$. aquatica has ascospores without appendages, but with a large mucilaginous sheath constricted in the central septum. Vaginatispora armatispora differs from $V$. appendiculata in having ascospores lacking guttules, while $V$. appendiculata has distinct large guttules in each cell, Vaginatispora armatispora differs from $V$. appendiculata in having ascospores lacking guttules, while $V$. appendiculata has distinct large guttules in each cell, ascospore measurements are also different with $V$. appendiculata larger $(40-45 \times 10-15 \mu \mathrm{m})$ than those of $V$. armatispora $(28-38 \times$ 7-9.8 $\mu \mathrm{m}$ ). Read et al. (1997) have shown that the appendage in $V$. armatispora is quite complex: external to the bipartite mesosporium there is the episporium surround by a mucilaginous sheath which is extended apically to form 3-7 $\mu \mathrm{m}$ tapering, curved polar appendage. An electron-dense fibrillar layer is located external to the sheath. This ultra-structural observation may become a mandatory additional criterion for a complete description of micro fungi, especially taxa with a sheath. The phylogenetic significance of the ultrastructural variation should be further investigated.

Consequently we introduce a new species $V$. appendiculata to accommodate the fungus collected from dead twigs from southern Thailand. Most of the members of Vaginatispora were collected from submerged wood in freshwater and mangroves in marine environments. Our species was collected from a terrestrial habitat, but it was also a well moistened environment near to a waterfall. Thus, Vaginatispora is most likely to be a freshwater genus.

\section{Acknowledgments}

This work was supported by the International Research Group Program (IRG-14-27), Deanship of Scientific Research, King Saud University, Saudi Arabia. Also we would like to thank Humidtropics, a CGIAR Research Program that aims to develop new opportunities for improved livelihoods in a sustainable environment, for partially funding this work.

\section{References}

Ariyawansa HA, Hyde KD, Jayasiri SC, Buyck B, Kandawatte WTC, Cui YY, Dai DQ, Dai YC, Daranagama DA, Jayawardena RS, Lücking R, Ghobad-Nejhad M, Niskanen T, Thambugala KM, Voigt K, Zhao RL, Boonmee S, Bahkali AH, Chen J, Cui BK, Dayarathne MC, Dissanayake AJ, Ekanayaka AH, Hashimoto A, Hongsanan S, Jones EBG, Larsson E, Lewis D, Li WJ, Li QR, Liu JK, Luo ZL, Maharachchikumbura SSN, Mapook A, McKenzie EHC, Norphanphoun C, Pang KL, Perera RH, Phookamsak R, Phukhamsakda C, Randrianjohany E, Senanayake IC, Singtripop C, Shang Q, Tanaka K, Tian Q, Tian CM, Tibpromma S, Verbeken A, Abdel-Wahab MA, Wanasinghe DN, Wijayawardene NN, Zhang JF, Zhang H, Abdel-Aziz FA, Adamčík S, Ammirati JF, Bulgakov T, Cabral AL, Callaghan TM, Callac P, Chang CH, Coca LF, Dal-Forno M, Dollhofer V, Fliegerová K, Greiner K, Griffith GW, Ho HM, Hofstetter V, Jeewon R, Kang JC, Kirk PM, Kytövuori I, Lawrey JD, Li JXH, Liu ZY, Zhong X, L, Liimatainen K, Lumbsch HT, Matumura M, Moncada B, Nuankaew S, Parnmen S, Santiago MDA, Sato G, Sommai S, Song Y, De Souza CAF, De Souza-Motta CM, Su HY, Suetrong S, Wang Y, Wei SF, Wen TC, Shen H, Yuan HS, Zhou LW, Reblova M, Fournier J, Camporesi E. 2015a - Fungal Diversity Notes 111-252-Taxonomic and phylogenetic contributions to fungal taxa. Fungal Diversity 75, 27-274. (DOI 10.1007/s13225-015-0346-5). 
Ariyawansa HA, Tanaka K, Thambugala KM, Phookamsak R, Tian Q, Camporesi E, Hongsanan S, Monkai J, Wanasinghe DN, Chukeatirote E, Kang JC, Xu JC, McKenzie EHC, Jones EBG, Hyde KD. 2014 - A molecular phylogenetic reappraisal of the Didymosphaeriaceae (= Montagnulaceae). Fungal Diversity 68, 69-104. (DOI 10.1007/s13225-014-0305-6)

Ariyawansa HA, Thambugala KM, Manamgoda DS, Jayawardena R, Camporesi E, Boonmee S, Wanasinghe DN, Phookamsak R, Hongsanan S, Singtripop C, Chukeatirote E, Kang JC, Jones EBG, Hyde KD. 2015b - Towards a natural classification and backbone tree for Pleosporaceae. Fungal Diversity 71, 85-139. (DOI 10.1007/s13225-015-0323-z)

Boonmee S, KoKo TW, Chukeatirote E, Hyde KD, Chen H, Cai L, McKenzie EHC, Jones EBG, Kodsueb R, Hassan BA. 2012 - Two new Kirschsteiniothelia species with Dendryphiopsis anamorphs cluster in Kirschsteiniotheliaceae fam. nov. Mycologia 104, 698-714. (DOI: 10.3852/11-089)

Boonmee S, Zhang Y, Chomnunti P, Chukeatirote E, Tsui CKM, Bahkali AH, Hyde KD. 2011 Revision of lignicolous Tubeufiaceae based on morphological reexamination and phylogenetic analysis. Fungal Diversity 51, 63-102. (DOI 10.1007/s13225-011-0147-4)

Cai L, Guo XY, Hyde KD. 2008 - Morphological and molecular characterization of a new anamorphic genus Cheirosporium, from freshwater in China. Persoonia 20, 53-58. (DOI 10.3767/003158508X314732)

Cai L, Jeewon R, Hyde KD. 2006 - Phylogenetic investigations of Sordariaceae based on multiple gene sequences and morphology. Mycological Research 110, 137-150. (DOI 10.1016/j.mycres.2005.09.014)

Chomnunti P, Hongsanan S, Hudson BA, Tian Q, Peršoh D, Dhami MK, Alias AS, Xu J, Liu X, Stadler M, Hyde KD. 2014 - The Sooty Moulds. Fungal Diversity 66, 1-36. (DOI 10.1007/s13225-014-0278-5)

Hall TA. 1999 - BioEdit: a user-friendly biological sequence alignment editor and analysis program for Windows 95/98/NT. In: Nucleic Acids Symposium Series 41, 95-98

Huelsenbeck JP, Ronquist F. 2001 - MRBAYES: Bayesian inference of phylogenetic trees. Bioinformatics 17, 754-755. (DOI 10.1093/bioinformatics/17.8.754)

Hyde KD, Jones EBG, Liu JK, Ariyawansa H, Boehm E, Boonmee S, Braun U, Chomnunti P, Crous PW, Dai DQ, Diederich P, Dissanayake A, Doilom M, Doveri F, Hongsanan S, Jayawardena R, Lawrey JD, Li YM, Liu YX, Lücking R, Monkai J, Muggia L, Nelsen MP, Pang KL, Phookamsak R, Senanayake IC, Shearer CA, Suetrong S, Tanaka K, Thambugala KM, Wijayawardene NN, Wikee S, Wu HX, Zhang Y, Aguirre-Hudson B, Alias SA, Aptroot A, Bahkali A, Bezerra JL, Bhat DJ, Camporesi E, Chukeatirote E, Gueidan C, Hawksworth DL, Hirayama K, Hoog SD, Kang JC, Knudsen K, Li WJ, Li XH, Liu ZY, Mapook A, Mckenzie EHC, Miller AN, Mortimer PE, Phillips AJL, Raja HA, Scheuer C, Schumm F, Taylor JE, Tian Q, Tibpromma S, Wanasinghe DN, Wang Y, Xu JC, Yacharoen S, Yan JY, Zhang M. 2013 - Families of Dothideomycetes. Fungal Diversity 63, 1-313. (DOI 10.1007/s13225-013-0263-4)

Hyde KD, Vrijmoed LLP, Chinnaraj S, Jones EBG. 1992 - Massarina armatispora sp. nov., a new intertidal ascomycete from mangroves. Botanica Marina 35, 325-328. (DOI: 10.1515/botm.1992.35.4.325)

Hyde KD. 1995 - Tropical Australasian fungi. IX. Vaginatispora aquatica gen. et sp. nov. Nova Hedwigia 61, 233-241.

Jayasiri SC, Hyde KD, Ariyawansa HA, Bhat J, Buyck B, Cai L, Dai YC, Abdelsalam KA, Ertz D, Hidayat I, Jeewon R, Jones EBG, Bahkali AH, Karunarathna SC, Liu JK, Luangsa-Ard JJ, Lumbsch HT, Maharachchikumbura SSN, Mckenzie EHC, Moncalvo JM, Ghobadnejhad M, Nilsson H, Pang KA, Pereira OL, Phillips AJL, Raspé O, Rollins AW, Romero AI, Etayo J, Selçuk F, Stephenson SL, Suetrong S, Taylor JE, Tsui CKM, Vizzini A, Abdel-Wahab MA, Wen TC, Boonmee S, Dai DQ, Daranagama DA, Dissanayake AJ, Ekanayaka AH, Fryar SC, Hongsanan S, Jayawardena Rs, Li WJ, Perera RH, Phookamsak R, De Silva NI, Thambugala KM, Tian Q, Wijayawardene NN, Zhao RL, Zhao Q, Kang JC, Promputtha I. 2015 - The 
Faces of Fungi database: fungal names linked with morphology, phylogeny and human impacts. Fungal Diversity 74, 3-18. (DOI 10.1007/s13225-015-0351-8)

Katoh K, Standley K. 2013. MAFFT Multiple Sequence Alignment Software Version 7: Improvements in Performance and Usability. Molecular Biology \& Evolution 30, 772-780. (DOI 10.1093/molbev/mst010)

Kishino H, Hasegawa M. 1989 - Evaluation of the maximum likelihood estimate of the evolutionary tree topologies from DNA sequence data, and the branching order in hominoidea. Journal of Molecular Evolution 29, 170-179. (DOI 10.1007/BF02100115)

Li GJ, Hyde KD, Zhao RL, Sinang H, Abdel-Aziz FA, Abdel-Wahab MA, Silva GA, Ammirati J, Ariyawansa HA, Baghela A, Bahkali AH, Beug M, Bojantchev D, Boonpratuang T, Bulgakov T, Camporesi E, Castilho BM, Ceska O, Chakraborty D, Chen JJ, Chethana KWT, Consiglio G, Cui BK, Dai YC, Daranagama DA, Das K, Dayarathna MC, Crop ED, De Oliveira RJV, De Souza CAF, Dentinger BTM, Dissanayake AJ, Doilom M, DrechslerSantos ER, Ghobad-Nejhad M, Gilmore SP, Góes-Neto A, Gorczak M, Haitjema CH, Hapuarachchi KK, Hashimoto A, He MQ, Henrique JG, Henske JK, Hirayama K, Ivanildo DSJ, Jayasiri SC, Jayawardena RS, Jeon SJ, Jesus AL, Jones EBG, Josefina IM, Karunarathna SC, Kirk PM, Konta S, Kuhnert E, Langer E, Lee HS, Lee HB, Li WJ, Li XH, Liimatainen K, Lima DX, Lin CG, Luangsa-ard JJ, Lücking R, Lumbsch HT, Lumyong S, Maharachchikumbura SSN, Malibiran LE, Marano AV, Matsumura M, McKenzie EHC, Nguyen TTT, Niskanen T, Norphanphoun C, O’Malley MA, Pablo A, Parnmen S, Pawłowska J, Perera RH, Phookamsak R, Phukhamsakda C, Pires-Zottarelli CLA, Raspé O, Reck MA, Santiago ALCMDA, Setti L, Shang QJ, Singh SK, Sir EB, Solomon KV, Song J, Srikitikulchai P, Stadler M, Suetrong S, Takahashi H, Takahashi T, Tanaka K, Tang LP, Thambugala KM, Theodorou MK, Thongbai B, Thummarukcharoen T, Tian Q, Tibpromma S, Verbeken A, Vizzini A, Vlasák J, Voigt K, Wanasinghe DN, Wang Y, Weerakoon G, Wen HA, Wen TC, Wijayawardene NN, Wongkanoun S, Wrzosek M, Xiao YP, Yan JY, Yang J, Yang SD, Young JT, Yu H, Zhang JF, Zhao J, Zhou LW. 2016 - Fungal diversity notes 253370 - Taxonomic and phylogenetic contributions to fungal taxa. Fungal Diversity in press

Liew ECY, Aptroot A, Hyde KD. 2002 - An evaluation of the monophyly of Massarina based on ribosomal DNA sequences. Mycologia 94, 803-813.

Liu JK, Hyde KD, Jones EBG, Ariyawansa HA, Bhat DJ, Boonmee S, Maharachchikumbura SSN, Mckenzie EHC, Phookamsak R, Phukhamsakda C, Shenoy BD, Abdel-Wahab MA, Buyck B, Chen J, Chethana KWT, Singtripop C, Dai DQ, Dai YC, Daranagama DA, Dissanayake AJ, Doilom M, D'souza MJ, Fan XL, Goonasekara ID, Hirayama K, Hongsanan S, Jayasiri SC, Jayawardena RS, Karunarathna SC, Li WJ, Mapook A, Norphanphoun C, Pang KL, Perera RH, Peršoh D, Pinruan U, Senanayake IC, Somrithipol S, Suetrong S, Tanaka K, Thambugala KM, Tian Q, Tibpromma S, Udayanga D, Wijayawardene NN, Wanasinghe DN, Wisitrassameewong K, Zeng XY, Abdel-Aziz FA, Adamčík S, Bahkali AH, Boonyuen N, Bulgakov T, Callac P, Chomnunti P, Greiner K, Hashimoto A, Hofstetter V, Kang JC, Lewis D, Li XH, Liu XZ, Liu ZY, Matsumura M, Mortimer PE, Rambold G, Randrianjohany E, Sato G, Sri-Indrasutdhi V, Tian CM, Verbeken A, Von Brackel W, Wang Y, Wen TC, Xu JC, Yan JY, Zhao RL, Camporesi E. 2015 - Fungal diversity notes 1-110: taxonomic and phylogenetic contributions to fungal species. Fungal Diversity 72, 1-197. (DOI $10.1007 / \mathrm{s} 13225-015-0324-y)$

Liu JK, Phookamsak R, Doilom M, Wiki S, Mei LY, Ariyawansa HA, Boonmee S, Chomnunti P, Dai DQ, Bhat DJ, Romero AI, Xhuang WY, Monkai J, Jones EBG, Chukeatirote E, KoKo TW, Zhoa YC, Wang Y, Hyde KD. 2012 - Towards a natural classification of Botryosphaeriales. Fungal Diversity 57, 149-210. (DOI 10.1007/s13225-012-0207-4)

Liu JK, Phookamsak R, Jones EBG, Zhang Y, Ko-Ko TW, Hu HL, Boonmee S, Doilom M, Chukeatirote E, Bahkali AH, Wang Y, Hyde KD. 2011 - Astrosphaeriella is polyphyletic, with species in Fissuroma gen. nov., and Neoastrosphaeriella gen. nov. Fungal Diversity 51, 135-154. (DOI 10.1007/s13225-011-0142-9) 
Phookamsak R, Liu JK, Mckenzie EHC, Manamgoda DS, Chatpapamon C, Ariyawansa H, Thambugala KM, Dai DQ, Camporesi E, Chukeatirote E, Wijayawardene NN, Bahkali AH, Mortimer PE, Xu JC, Hyde KD. 2014 - Revision of Phaeosphaeriaceae. Fungal Diversity 68, 159-238. (DOI: 10.1007/s13225-014-0308-3)

Phookamsak R, Norphanphoun C, Tanaka K, Dai DQ, Luo ZL, Liu JK, Su HY, Bhat DJ, Bahkali AH, Mortimer PE, Xu JC, Hyde KD. 2015 - Towards a natural classification of Astrosphaeriella-like species; introducing Astrosphaeriellaceae and Pseudoastrosphaeriellaceae fam. nov. and Astrosphaeriellopsis, gen. nov. Fungal Diversity 74, 143-197. (DOI 10.1007/s13225-015-0352-7)

Posada D, Crandall KA. 1998 - Modeltest: testing the model of DNA substitution. Bioinformatics 14:817-818 (DOI 10.1093/bioinformatics/14.9.817).

Rambaut A. 2012 - FigTree version 1.4.0. Available at http://ree.bio.ed.ac.uk/software/figtree/

Rannala B, Yang Z. 1996 - Probability distribution of molecular evolutionary trees: a new method of phylogenetic inference. Journal of Molecular Evolution 43, 304-311. (DOI 10.1007/BF02338839)

Read SJ, Jones EBG, Moss ST. 1997 - Ultrastructural observation of asci, ascospores and appendages of Massarina armatispora (Ascomycota). Mycoscience 38, 141-146. (DOI 10.1007/BF02460849)

Rehner S. $2001 \quad-\quad$ Primers for Elongation Factor 1- $\alpha$ (EF1- $\alpha)$. http://ocid.NACSE.ORG/research/deephyphae/EF1primer.pdf.

Silvestro D, Michalak I. 2012 - raxmlGUI: a graphical front-end for RAxML. Organisms Diversity \& Evolution 12, 335-337. (DOI 10.1007/s13127-011-0056-0)

Stamatakis A. 2006 - RAxML-VI-HPC: Maximum likelihood-based phylogenetic analyses with thousands of taxa and mixed models. Bioinformatics 22, 2688-2690. (DOI 10.1093/bioinformatics/bt1446)

Swofford DL. 2002 - PAUP: phylogenetic analysis using parsimony, version 4.0 b10. Sinauer Associates, Sunderland (DOI 10.1111/j.0014-3820.2002.tb00191.x)

Thambugala KM, Ariyawansa HA, Li YM, Boonmee S, Hongsanan S, Tian Q, Singtripop C, Bhat DJ, Camporesi E, Jayawardena R, Liu ZY, Chukeatirote E, Hyde KD. 2014 - Dothideales. Fungal Diversity 68, 105-158. (DOI 10.1007/s13225-014-0303-8)

Thambugala KM, Hyde KD, Tanaka K, Tian Q, Wanasinghe DN, Ariyawansa HA, Jayasiri SC, Boonmee S, Camporesi E, Hashimoto A, Hirayama K, Schumacher RK, Promputtha I, Liu ZY. 2015 - Towards a natural classification and backbone tree for Lophiostomataceae, Floricolaceae and Amorosiaceae fam. nov. Fungal Diversity 74, 199-266. (DOI 10.1007/s13225-015-0348-3)

Tian Q, Liu JK, Hyde KD, Wanasinghe DN, Boonmee S, Jayasiri SC, Luo ZL, Taylor JE, Phillips AJL, Bhat DJ, Li WJ, Ariyawansa HA, Thambugala KM, Jones EBG, Chomnunti P, Bahkali AL, Xu JC, Camporesi E. 2015 - Phylogenetic relationships and morphological reappraisal of Melanommataceae (Pleosporales). Fungal Diversity 74, 267-324. (DOI 10.1007/s13225-0150350-9)

Vilgalys R, Hester M. 1990 - Rapid genetic identification and mapping of enzymatically amplified ribosomal DNA from several Cryptococcus species. Journal of Bacteriology 172, 4238-4246.

Wanasinghe DN, Jones EBG, Camporesi E, Boonmee S, Ariyawansa HA, Wijayawardene NN, Mortimer PE, Xu JC, Yang JB, Hyde KD. 2014a - An exciting novel member of Lentitheciaceae in Italy from Clematis vitalba. Cryptogamie Mycologie 35, 323-337. (DOI 10.7872/crym.v35.iss4.2014.323)

Wanasinghe DN, Jones EBG, Camporesi E, Boonmee S, Karunarathna SC, Thines M, MOrtimer PE, Xu J, Hyde KD. 2014b - Dematiopleospora mariae gen. sp. nov., from Ononis spinosain Italy. Cryptogamie Mycologie 35, 105-117. (DOI 10.7872/crym.v35.iss2.2014.105)

Wanasinghe DN, Jones EBG, Camporesi E, Mortimer PE, Xu JC, Bahkali Ah, Hyde KD. 2015 The genus Murispora. Cryptogamie Mycologie 36, 419-448. (DOI 10.7872/crym/v36.iss4.2015.419) 
White TJ, Bruns T, Lee J, Taylor SB. 1990 - Amplification and direct sequencing of fungal ribosomal RNA genes for phylogenetics. In: Innis MA, Gelfand DH, Sninsky JJ, White TJ (eds), PCR protocols: a guide to methods and applications: 315-322. Academic Press, San Diego, California, USA.

Wijayawardene NN, Crous PW, Kirk PM, Hawksworth DL, Boonmee S, Braun U, Dai DQ, D'souza MJ, Diederich P, Dissanayake A, Doilom M, Hongsanan S, Jones EBG, Groenewald JZ, Jayawardena R, Lawrey JD, Liu JK, Luecking R, Madrid H, Manamgoda DS, Muggia L, Nelsen MP, Phookamsak R, Suetrong S, Tanaka K, Thambugala KM, Wanasinghe DN, Wikee S, Zhang Y, Aptroot A, Ariyawansa HA, Bahkali AH, Bhat DJ, Gueidan C, Chomnunti P, De Hoog GS, Knudsen K, Li WJ, Mckenzie EHC, Miller AN, Phillips AJL, Piatek M, Raja HA, Shivas RS, Slippers B, Taylor JE, Tian Q, Wang Y, Woudenberg JHC, Cai L, Jaklitsch WM, Hyde KD. 2014a - Naming and outline of Dothideomycetes-2014 including proposals for the protection or suppression of generic names. Fungal Diversity 69, 1-55. (DOI 10.1007/s13225-014-0309-2)

Wijayawardene NN, Hyde KD, Bhat DJ, Camporesi E, Schumacher RK, Chethana KWT, Wikee S, Bahkali AH, Wang Y. 2014b - Camarosporium-like species are polyphyletic in Pleosporales; introducing Paracamarosporium and Pseudocamarosporium gen. nov. in Montagnulaceae. Cryptogamie Mycologie 35, 177-198. (DOI 10.7872/crym.v35.iss2.2014.177)

Wijayawardene NN, Hyde KD, Camporesi E, Bhat DJ, Goonasekara ID, Nadeeshan D, Camporesi E, Schumacher RK, Wang Y. 2015 - Additions to brown spored coelomycetous taxa in Massarinae, Pleosporales: introducing Phragmocamarosporium gen. nov. and Suttonomyces gen. nov. Cryptogamie Mycologie 36, 213-224. (DOI 10.7872/crym/v36.iss2.2015.213)

Wijayawardene NN, Hyde KD, Wanasinghe DN, Papizadeh M, Goonasekara ID, Camporesi E, Bhat DJ, McKenzie EHC, Phillips AJL, Diederich P, Tanaka K, Li WJ, Tangthirasunun N, Phookamsak R, Dai DQ, Dissanayake AJ, Weerakoon G, Maharachchikumbura SSN, Hashimoto A, Matsumura M, Wang Y. 2016 - Taxonomy and phylogeny of dematiaceous coelomycetes. Fungal Diversity in press

Wu ZH, Wang TH, Huang W, Qu YB. 2001 - A simplified method for chromosome DNA preparation from filamentous fungi. Mycosystema 20, 575-577.

Zhang H, Hyde KD, Zhao Y, McKenzie EH, Zhou D. 2014 - Freshwater ascomycetes: Lophiostoma vaginatispora comb. nov. (Dothideomycetes, Pleosporales, Lophiostomaceae) based on morphological and molecular data. Phytotaxa 176, 184-191. (DOI 10.11646/phytotaxa.176.1.18)

Zhaxybayeva O, Gogarten JP. 2002 - Bootstrap, Bayesian probability and maximum likelihood mapping: exploring new tools for comparative genome analyses. BMC Genomics 3:4 (DOI 10.1186/1471-2164-3-4) 